\title{
Glucomannan- and glucomannan plus spirulina-enriched pork affect liver fatty acid profile, LDL receptor expression and antioxidant status in Zucker fa/fa rats fed atherogenic diets
}

\author{
Laura González-Torresa, Cátia Matos ${ }^{a}$, Miguel Vázquez-Velascoa, Jorge A. Santos-López $\mathbb{0}^{\mathrm{b}}$, Iria Sánchez- \\ Martíneza , Camino García-Fernández ${ }^{c}$, Sara Bastida $\mathbb{1}^{a}$, Juana Benedí $\mathbb{1}^{\mathrm{b}}$ and Francisco J. Sánchez-Muniz (1) ${ }^{\mathrm{a}}$ \\ aDepartamento de Nutrición y Bromatología I (Nutrición), Facultad de Farmacia, Universidad Complutense de Madrid, Madrid, Spain; \\ bDepartmento de Farmacología, Facultad de Farmacia, Universidad Complutense de Madrid, Madrid, Spain; 'Departmento de Nutrición, \\ Facultad de Veterinaria, Universidad de León, León, Spain
}

\begin{abstract}
We evaluated the effects of glucomannan or glucomannan plus spirulina-restructured pork (RP) on liver fatty acid profile, desaturase/elongase enzyme activities and oxidative status of Zucker fa/ fa rats for seven weeks. Control (C), glucomannan (G) and glucomannan/spirulina (GS)-RP; HC (cholesterol-enriched control), HG and HGS (cholesterol-enriched glucomannan and glucomannan/spirulina-RP) experimental diets were tested. Increased metabolic syndrome markers were found in C, G and GS rats. Cholesterol feeding increased liver size, fat, and cholesterol and reduced antioxidant enzyme levels and expressions. Cholesterolemia was lower in HG and HGS than in HC. GS vs. G showed higher stearic but lower oleic levels. SFA and PUFA decreased while MUFA increased by cholesterol feeding. The arachidonic/linoleic and docosahexaenoic/alphalinolenic ratios were lower in $\mathrm{HC}, \mathrm{HG}$, and $\mathrm{HGS}$ vs. $\mathrm{C}, \mathrm{G}$, and $\mathrm{GS}$, respectively, suggesting a delta-6-elongase-desaturase system inhibition. Moreover, cholesterol feeding, mainly in HGS, decreased low-density-lipoprotein receptor expression and the delta-5-desaturase activity and increased the delta-9-desaturase activity. In conclusion, the liver production of highly unsaturated fatty acids was limited to decrease their oxidation in presence of hypercholesterolaemia. Glucomannan or glucomannan/spirulina-RP has added new attributes to their functional properties in meat, partially arresting the negative effects induced by high-fat-high-cholesterol feeding on the liver fatty acid and antioxidant statuses.
\end{abstract}

\section{ARTICLE HISTORY}

Received 23 February 2016

Revised 17 November 2016

Accepted 17 November

2016

\section{KEYWORDS}

Glucomannan; spirulina; functional meats; oxidative stress; fatty acid profile; hypercholesterolemia

\section{Introduction}

The Zucker fa/fa rat is an animal model predisposed to obesity and metabolic syndrome. This strain is very sensitive to hypercaloric and hyperlipidic diets [1] and therefore is prone to hypercholesterolemia. Hypercholesterolemic diets can affect the expression levels of antioxidant enzymes [2,3] while free radicals caused by oxidative stress can lead to cell and tissue damage possibly resulting in cancer or cardiovascular disease $[4,5]$.

Meat and meat products are essential in a balanced and optimal diet as they contain a large number and amount of nutrients such as proteins, minerals, vitamins and fats [6]. Although meat in the diet has been indicative of health and prosperity for centuries, in recent decades its content in saturated fatty acids has been associated with cardiovascular disease (CVD), mainly with an increase in low density lipoproteins (LDL) [7].

Food technology is responsible for quantitative and qualitative modifications in meat and meat matrices creating functional meat products. Our group has done extensive work on restructured pork (RP) enriched with different ingredients such as algae, omega-3 fatty acids and minerals [8,9]. Those RP must be able to provide a beneficial effect on one or more selective body functions, improving health and wellness while reducing the risk of disease [6]. Functional ingredients such as Spirulina platensis or Konjac glucomannan are used in these modifications. Spirulina is a microalga rich in minerals, antioxidant compounds (mainly carotenoids and phycocyanin) and a biliprotein pigment with hypocholesterolemic activity [10]. Konjac glucomannan is an indigestible polysaccharide extracted from the tubercle of Amorphophallus

CONTACT Francisco J. Sánchez-Muniz frasan@ucm.es Departamento de Nutrición y Bromatología I. Facultad de Farmacia, Universidad Complutense de Madrid, Plaza Ramón y Cajal s/n, 28040, Madrid, Spain

(4) The supplemental data for this article can be accessed here.

(c) 2016 The Author(s). Published by Informa UK Limited, trading as Taylor \& Francis Group.

This is an Open Access article distributed under the terms of the Creative Commons Attribution License (http://creativecommons.org/licenses/by/4.0/), which permits unrestricted use, distribution, and reproduction in any medium, provided the original work is properly cited. 
konjac [11]. Some studies suggest the usefulness of Konjac glucomannan in the treatment of obesity, dyslipidemia and diabetes [12]. Some studies also suggest that glucomannan promotes satiety [13], has a prebiotic effect [14] and acts as an immunomodulator [15] or hypocholesterolemic [16]. Glucomannan has been added to squid surimi and promising results on cholesterolemia and antioxidant status have been found in cholesterol-fed rats, mostly when associated with spirulina [17]. However, controversial results were observed in some inflammatory biomarkers $[17,18]$. We very recently published results on the effects of glucomannan and glucomannan/spirulina-enriched $\mathrm{RP}$ in atherogenic diets on lipids and lipoproteins [19]. Both RP were able to mitigate the cholesterolemic effects of dietary cholesterol by decreasing the level of atherogenic lipoproteins, especially in cholesterol-fed animals.

Based on previous research done by our group, we hypothesized that at hypercholesterolemic status the liver increases the esterification of free-cholesterol with oleic acid [20]. Body weight gain in cholesterolfed animals was also reduced probably due to a hormone-sensitive lipase (HSL) increase accelerating the release of free fatty acids from adipose tissue [19]. Nevertheless, either liver fatty acid profile or LDL receptor $(L d l r)$ expression has been tested in fa/fa rats in an attempt to discover a potential mechanism linking all these results.

The biological mechanisms linking estimated desaturase activity with obesity and diabetes mellitus type 2 (T2DM) are still unclear. Delta-6 desaturase is the ratelimiting step along the PUFA pathway which includes arachidonic acid, a precursor from eicosanoids that may act as an inflammation mediator [21]. Increased delta-5-desaturase (D5D) activity has been associated with high plasma concentrations of eicosapentaenoic (EPA) and docosahexaenoic (DHA) acids, which have anti-inflammatory properties and triglyceride-lowering effects [22]. Stearoyl-CoA desaturase-1 (SCD1) is the rate-limiting enzyme in the synthesis of MUFAs [23]. Genetic variants of SCD1 have been associated with dyslipidemia, inflammation and increased liver fat in T2DM [24].

The relevance of the present work lies in the possible application of Glucomannan- and spirulina-RP to improve the liver fatty acid and antioxidant status profiles of hypercholesterolemic rats. Thus, we hypothesized that adding glucomannan or glucomannan plus spirulina to RP would ameliorate the negative effect of cholesterol feeding on both profiles. As no studies have been performed to evaluate these changes, the aims of this paper were to evaluate the effect that glucomannan/glucomannan plus spirulina-RP consumption in $\mathrm{fa} / \mathrm{fa}$ rats have on main liver characteristics: (a) size, fat and cholesterol content; (b) fatty acid composition and Ldlr expression; (c) desaturases and desaturase-elongase activities; (d) antioxidant status based on the quantification of activities and expressions of several antioxidant enzymes.

\section{Material and methods}

\section{Diet preparation and experimental design}

This study was approved by the Spanish Science and Technology Advisory Committee (project AGL 2008-04892-C03-02 and Consolider Ingenio 2010, CSD 2007-00016) and by the ethics committee of the Complutense University of Madrid (Spain). All experiments were performed in compliance with Directive 2003/65/EEC of the European Parliament and of the Council of 22 July 2003 on the protection of animals used for scientific purposes. A total of thirty-six growing male Zucker fa/fa rats with an initial body weight of approximately $120 \mathrm{~g}$ were obtained from Harlan Laboratories Models (Harlan, SL, Barcelona, Spain). The animals were housed individually in metabolic cells in a temperature-controlled room $\left(22.3 \pm 1.9^{\circ} \mathrm{C}\right)$ with a $12 \mathrm{~h}$ light-dark cycle. The rats were fed commercial pellets (Panlab, Barcelona, Spain) for one week to adapt to environmental conditions and then distributed into six groups of six animals each according to their average body weight. Rats were fed the experimental diets for 7 weeks. Food consumption was measured daily and body weight once per week. Tap water was provided ad libitum over the experimental period with an average consumption of $10 \mathrm{~mL} / 100 \mathrm{~g}$ body weight/day. In order to avoid inter-assay variations that could affect the comparison of data from the different groups, at the end of the experiment fasting rats were taken one at a time from each of the six groups, anesthetized with pentobarbital $(45 \mathrm{mg} / \mathrm{kg}$ ) and euthanized by extracting blood from the descending aorta with a syringe. Then, plasma was separated by centrifugation at $2000 \mathrm{~g}$ for $10 \mathrm{~min}$. Livers were collected and weighted immediately after blood extraction.

Glucomannan (Amorphophallus konjac; powder from Guinama, S.L.U., Valencia, Spain; $22.5 \mathrm{~g} / \mathrm{kg}$ diet) and Spirulina (Arthrospira maxima; micronized powder from Arkopharma, Madrid, Spain; $3.0 \mathrm{~g} / \mathrm{kg}$ diet) were used in the preparation of diets and calculated according to previous studies from Hozumi et al. (1995), Bermejo-Bescós et al. (2008), and Ou et al. (2013). Pork was purchased at a local market, then 
freeze-dried and mixed with the rest of the ingredients until fully homogenous to form the restructured pork (RP). The following six semi-synthetic experimental diets were prepared: control diet with no added cholesterol (C) was composed of a homogeneous mixture of $85 \%$ rodent diet (AIN-93M purified rodent diet; Dyets, Inc., Bethlehem, PA, USA) [25] and 15\% freeze-dried RP (with 15\% microcrystalline cellulose); glucomannan normocholesterolaemic diet $(G)$ consisted of a mixture of AIN-93M no.102635 feed (85\%) and freeze-dried glucomannan-enriched RP (15\%); glucomannan plus spirulina normocholesterolaemic diet (GS) consisted of a mixture of AIN-93M no.102635 feed $(85 \%)$ and freeze-dried glucomannan plus spirulina-enriched RP (15\%); cholesterol-enriched control diet (HC) was identical to diet C but with $2.43 \%$ cholesterol (95-98\% purity) and $0.49 \%$ cholic acid (98\% purity) replacing an equal amount of corn starch (AIN-93M no. 102,636 diet); cholesterol-enriched glucomannan diet (HG) was the $\mathrm{G}$ diet enriched with cholesterol (2.43\%) and cholic acid (0.49\%); the cholesterol-enriched glucomannan plus spirulina diet (HGS) consisted of the GS diet enriched with cholesterol $(2.43 \%)$ and cholic acid (0.49\%). The amount of cholesterol and cholic acid added to diet was based on previous studies [26]. Diets were designed to cover rat nutritional requirements. Details of diet composition can be found in the Supplementary Table.

\section{Determination of fatty acid profile in liver}

Liver fat was extracted following the Folch method [27]. $50 \mathrm{mg}$ of fat were characterized in the form of methyl esters in capillary gas chromatography in accordance with the procedure followed by Carrapiso et al. [28]. Gas chromatography (GC) was performed using an HP 5890II (Hewlett Packard) equipped with a cold on-column injector and a flame ionization detector (FID). Individual fatty acid methyl esters (FAMEs) were separated with a $30 \mathrm{~m} \times 0.53 \mathrm{~mm}$ capillary column coated with FFAP-TPA stationary phase $(1 \mathrm{~mm}$ thickness). The GC conditions were as follows: oven temperature $220^{\circ} \mathrm{C}$ isothermal for $30 \mathrm{~min}$, injector and detector temperature $230{ }^{\circ} \mathrm{C}$. The flow rate of the carrier gas (nitrogen) was $2.6 \mathrm{ml} / \mathrm{min}$ and $0.1 \mathrm{ml}$ of solution was injected. Chromatographic data were recorded and integrated in an HP computer (HP Vectra QS/20) using a Hewlett Packard ChemStation A.01.14 software. Fatty acid methyl esters were identified by comparison of retention times with standards. Peak areas were corrected using FID response factors estimated from standards. The concentrations of FA ( $\mathrm{g} / 100 \mathrm{~g}$ methyl ester) were calculated by means of the internal standard (tridecanoic acid methyl ester) and sample weight. Some products-to-precursor ratios were used as surrogated indices of enzymes desaturase [24] or desaturase-elongase activities [29], using the following formulas:

Delta-6-elongase-desaturase:

(a) Docosahexahenoic acid/linolenic acid (C22:6 n-3/C18:3 n-3)

(b) Arachidonic acid/linoleic acid (C20:4n-6/ C18:2 n-6)

Stearoyl-CoA activity:

Palmitoleic acid/palmitic acid (C16:1 n-7/C16:0)

Oleoyl-CoA activity:

Oleic acid/stearic acid (C18:1 n-9/C18:0)

Delta 5 desaturase activity:

Arachidonic acid/eicosatrienoic acid (C20:4 n-6/ C20:3 n-6)

Delta-6 desaturase activity:

Gamma-linolenic acid/linoleic acid (C18:3 n-6/ C18:2 n-6)

\section{Western blotting and protein levels}

Total liver protein lysates were obtained and separated in $10 \%$ sodium dodecyl sulfate-poly-acrylamide gel electrophoresis (SDS-PAGE). Gels were then blotted onto PVDF Amersham Hybond-P membranes (GE Health-care, Buckinghamshire, UK) and incubated with their corresponding antibodies (anti- $\beta$-actin (A2228), anti-catalase (C0979), anti-superoxide dismutase (S2147) from Sigma-Aldrich, St. Louis, Missouri, USA; anti-glutathione peroxidase (Ab59546), from Abcam, Cambridge, UK; anti-glutathione reductase (sc-32886) from Santa Cruz Biotechnology, Dallas, Texas, USA). $\beta$-actin was used as loading control. Blots were developed by enhanced chemiluminescence using an Amersham ECL Plus Western Blotting Detection Reagent (GE Health-care, Buckinghamshire, $\mathrm{UK}$ ) according to manufacturer's instructions.

\section{RNA extraction}

Total RNA was isolated from $100 \mathrm{mg}$ of liver using Trizol (Invitrogen, Carlsbad, CA, USA) according to the manufacturer's instructions.

\section{RNA degradation}

Isolated RNA samples were treated with DNase I RNase-free, DNase treatment and removal reagents (Thermo Fisher Scientific, Waltham, Massachusetts, USA) to remove any contamination with genomic DNA. To check the potential RNA degradation the 
methodology published in Sample preparation techniques in analytical chemistry [30] was followed, we performed an agarose gel (1.3\%) to visualize the $18 \mathrm{~S}$ and $28 \mathrm{~S}$ bands and determine whether degradation have occurred during the isolation procedure, or if the RNA was degraded in the tissue prior to RNA isolation.

\section{RNA integrity and quantification}

To verify the integrity and to quantify RNA, the Fleige and Pfuffl protocol [31] with slight modifications was followed. This protocol permitted us to confirm the contaminants absence of RNA with proteins, salts, or organic reagents such as phenol or chloroform. Thus, we performed a quantity and integrity assessment using a UV/VIS spectrophotometer at multiple wave lengths: at $260 \mathrm{~nm}$ for nucleic acids; $270 \mathrm{~nm}$ for possible contaminants, mainly phenol derivates; $280 \mathrm{~nm}$ for proteins; and $310 \mathrm{~nm}$ for background and presence of salts or organic solvents. The $260 \mathrm{~nm} / 280 \mathrm{~nm}$ ratio was used to verify the RNA integrity, and the $260 \mathrm{~nm} /$ $310 \mathrm{~nm}$ ratio to verify the purity and the extraction performance. A $260 \mathrm{~nm} / 280 \mathrm{~nm}$ ratio greater than 1.9 was considered an acceptable indicator of good RNA quality.

\section{Gene expression and quantification by RT-PCR}

Total RNA of each sample $(1 \mu \mathrm{g})$ was reverse-transcribed to first-strand complementary DNA (cDNA) using a Revert Aid $\mathrm{H}$ minus first strand cDNA synthesis kit (Thermo Fisher Scientific, Waltham, Massachusetts, USA).

Relative superoxide dismutase $(\mathrm{Cu} / \mathrm{Zn}-\mathrm{SOD}, \mathrm{Mn}-$ SOD), catalase (CAT), glutathione peroxidise (GPx), glutathione reductase (GR) and Ldlr mRNA levels were quantified using RT-PCR with a LightCycler Real Time PCR Detection System (Roche Diagnostics, Indianapolis, Indiana, USA), using a $\mathrm{SYBR}^{\otimes}$ Green (Biotools, Madrid, Spain) as binding dye.

The PCR parameters were as follows: preincubation at $95{ }^{\circ} \mathrm{C}$ for 10 minutes followed by 40 cycles of denaturation at $95{ }^{\circ} \mathrm{C}$ for $5 \mathrm{~s}$, with an annealing temperature dependent of each couple primer $\left(55^{\circ} \mathrm{C}\right.$ for $\mathrm{Mn}$-SOD; $56^{\circ} \mathrm{C}$ for $\mathrm{Cu} / \mathrm{Zn}$-SOD, $67^{\circ} \mathrm{C}$ for $\mathrm{Ldlr}$ and 60 ${ }^{\circ} \mathrm{C}$ for CAT, GPx and GR), extension $72{ }^{\circ} \mathrm{C}$ for $30 \mathrm{~s}$. Melting curve $95{ }^{\circ} \mathrm{C}-65{ }^{\circ} \mathrm{C}-95{ }^{\circ} \mathrm{C}$ and cooling $40{ }^{\circ} \mathrm{C}$.

For each gene, primers were designed using average melting temperature settings near to $60{ }^{\circ} \mathrm{C}$ and Amplicon product sizes ranging from 70 to $180 \mathrm{bp}$. Primers sequences were obtained from GenBank of NCBI as follows:

\author{
Cu/Zn-SOD sense: 5' GCCGTGTGCGTGCTGAA 3' \\ $\mathrm{Cu} / \mathrm{Zn}$-SOD antisense: 5' TGACGATGCCGTGCTG \\ CATG $3^{\prime}$
}

Mn-SOD sense: 5' GACAAACCTGAGCCCTAAGGG 3'

Mn-SOD antisense: 5' CTTCTTGCAAACTATG 3'

CAT sense: 5' ATCAGGGATGCCATGTTGTT 3'

CAT antisense: 5' GGGTCCTTCAGGTGAGTTTG 3'

GR sense: 5' TCA CTG CTC CGC ACA TCC 3'

GR antisense: 5'CTC AAC ACC GCC AGC GTT CTCC $3^{\prime}$

GPx sense: 5'CCAATCAGTTCGGACACCAG 3'

GPx antisense: 5'AAAGTTCCAGGCAATGTCGT 3'

$L d l r$ sense: 5' CTGTATTCACGGTAGCCGCC 3'

Ldlr antisense: $5^{\prime}$ TGGGTCACATTGATGCAGCC 3'

$\beta$-Actin sense: 5' TACAACCTCCTTGCAGCTCC 3'

$\beta$-Actin antisense: 5'GGATCTTCATGAGGTAGTCA GTC 3'

All sample mRNA levels were normalized to their values of $\beta$-actin and the results expressed as fold changes of threshold cycle $(\mathrm{Ct})$ value relative to controls using the $2^{-\Delta \Delta \mathrm{Ct}}$ method [32].

\section{Determination of glutathione and redox index}

The determination of oxidized (GSSG) and reduced (GSH) glutathione was performed according to the Hissin and Hilf method [33]. This method is based on the ability of GSH to react with a fluorescent dye (o-phthaldialdehyde, OPT). Liver tissue was homogenized in phosphate-EDTA buffer $(0.1 \mathrm{M}$ sodium phosphate and $0.005 \mathrm{M}$ EDTA, $\mathrm{pH} 8$ ) at $100 \mathrm{mg} / \mathrm{mL}$, with the addition of $10 \mu \mathrm{L} / \mathrm{mL}$ of perchloric acid. It was then centrifuged at $10,000 \mathrm{rpm}$ for $10 \mathrm{~min}$ at $4{ }^{\circ} \mathrm{C}$. Fluorescence was measured at 350 and $420 \mathrm{~nm}$ (excitation and emission wavelengths, respectively). Concentrations were calculated using a standard GSH and GSSG curve. Results were expressed as $\mu \mathrm{g}$ glutathione/mg tissue. The calculated redox index (RI) indicates the antioxidant status of tissue obtained as follows: $\mathrm{RI}=\mathrm{GSSG} /(\mathrm{GSH}+\mathrm{GSSG})$.

\section{Plasma cholesterol, triglyceride, glucose levels and TyG index}

Total cholesterol was measured by following spectrophotometrically the formation of quinonimine at 
$505 \mathrm{~nm}$. Triglyceride and glucose levels were measured by following spectrophotometrically the formation of quinone with their corresponding lipases (lipoprotein lipase and phospholipase respectively) at $505 \mathrm{~nm}$. All reactions were determined from $10 \mu \mathrm{L}$ of plasma using standard enzymatic colorimetric kits from SPINREACT (San Esteve de Bas, Girona, Spain) according to manufacturer's instructions. Intra- and inter-assay variation coefficients for glucose, triglycerides and cholesterol were $<5 \%$.

The triglyceride-glucose index (TyG) was used to establish the existence of insulin resistance. This index has been considered a surrogate index of the HOMA index [34] and was calculated according to the following formula:

$$
\begin{gathered}
\text { TyG }=\mathrm{Ln}[\text { fasting plasma triglycerides }(\mathrm{mg} / \mathrm{dL}) \\
\left.{ }^{*} \text { fasting glucose }(\mathrm{mg} / \mathrm{dL}) / 2\right]
\end{gathered}
$$

\section{Statistical analyses}

All experiments were performed in triplicate. Statistical analyses were performed using the SPSS version 19.0 statistical analysis package (SPSS, Inc., Chicago, IL, USA). Results were expressed as means and standard deviations. A two-way ANOVA (cholesterol and diet) was used. Pairwise comparisons of diet responses between groups were made employing the Bonferroni test. Where variances were assumed to be unequal, the T2 of the Tamhane post hoc test was applied. The effect of cholesterol consumption was evaluated using an unpaired Student's $t$ test. Differences in growth rate induced by diets were assessed by the ANOVA test (SAS statistical packet 9.2).

\section{Results}

Figures $1(\mathrm{a}, \mathrm{b})$ show the relationship between cumulative feed intake and body weight gain, together with linear adjustment parameters $\left(r^{2}\right.$, slope and intercept, and their respective mean errors). All growth rate curves showed linear adjustments. Growth rate of $\mathrm{C}$ and $\mathrm{HC}$ rats significantly differ from those of their $\mathrm{G}$ and GS and HG and HGS counterparts, respectively. Supplementary dietary cholesterol significantly affected growth curves (HC vs. C, HG vs. G, and HGS vs. GS).

Table 1 shows that feed intake was significantly affected by the interaction of RP and cholesterol. Supplementary cholesterol and the type of RP influenced significantly weight gain, feed intake and feed conversion rate. The post hoc study showed that HC, HG, HGS vs. C, G, GS groups showed lower growth and lower feed intake while HC and HG presented lower feed conversion ratio than C and G. The addition of spirulina to glucomannan increased weight gain, final body weight and feed intake when compared to $\mathrm{C}$ animals. HG rats displayed higher feed intake than $\mathrm{HC}$ and HGS.

Liver weight, fat and cholesterol content together with the hepatosomatic index were significantly affected by cholesterol feeding but not by the RP-type or the cholesterol-RP type interaction. Liver fat was significantly higher in groups HG, HGS vs. G, GS. Plasma cholesterol increased in $\mathrm{HC}$ and $\mathrm{HG}$ vs. C and $G$ groups. HG and HGS rats had lower plasma cholesterol levels than those of the HC group. Plasma glucose was lower in HC vs. C group. Plasma glucose was lowered by cholesterol feeding and HC presented significantly lower glycemia than $\mathrm{C}$ rats. The TyG index was modified by the RP-cholesterol interaction and cholesterol effect. TyG was lower in HGS compared to HC rats.

$L d l r$ expression was significantly reduced by cholesterol feeding. Significant differences were observed in HC, HG and HGS rats vs. C, G and GS rats, respectively. Although no significant differences were observed between the non-cholesterol-fed groups, $L d l r$ expression was significantly lower in HG and HGS than HC rats. Table 2 shows that the percentage of arachidonic acid in liver was significantly affected by the type of $\mathrm{RP}^{\star}$ cholesterol interaction. The 'cholesterol factor' significantly affected the percentages of palmitic, stearic, oleic, linolenic, arachidonic, EPA, DHA, SFA, MUFA and PUFA. The 'RP factor' significantly affected the percentages of stearic, linoleic, linolenic, eicosatrienoic, arachidonic acids, SFA, and PUFA.

Palmitic acid (C16:0) percentage was significantly lower in HC vs. C and in HGS vs. GS rats but higher in HG vs. HC and HGS animals. Stearic acid (C18:0) percentage was lower in HGS $v s$. GS rats and in C and $\mathrm{G}$ vs. GS rats $(p<0.05)$. Oleic acid $(\mathrm{C} 18: \ln 9)$ percentages were higher in HC, HG and HGS than in their C, G and GS counterparts. GS oleic percentage was lower in Gs vs. $G$ rats. Linoleic acid (C18:2n6) percentage was lower in $G$ and GS vs. C livers. Gamma-linolenic acid (C18:3n6) percentage was higher in HG vs. G. Eicosenoic acid (C20:1) was higher in $\mathrm{HC}$ vs. C rats. Linolenic acid (C18:3n3) percentages were lower in $\mathrm{HG}$ vs. HC and HGS groups; $\mathrm{HC}$ vs. $\mathrm{C}$ and $\mathrm{HG}$ vs. $\mathrm{G}$ livers presented higher linolenic acid percentages. Eicosatrienoic acid (C20:3n6) percentages were lower in G and GS vs. C livers and in HGS vs. HC liver. Arachidonic acid (C20:4n6) percentage was lower in HC, HG, HGS vs. C, G, GS livers and in HG and HGS vs. HC livers. Eicosapentaenoic acid (C20:5n3) percentage was 

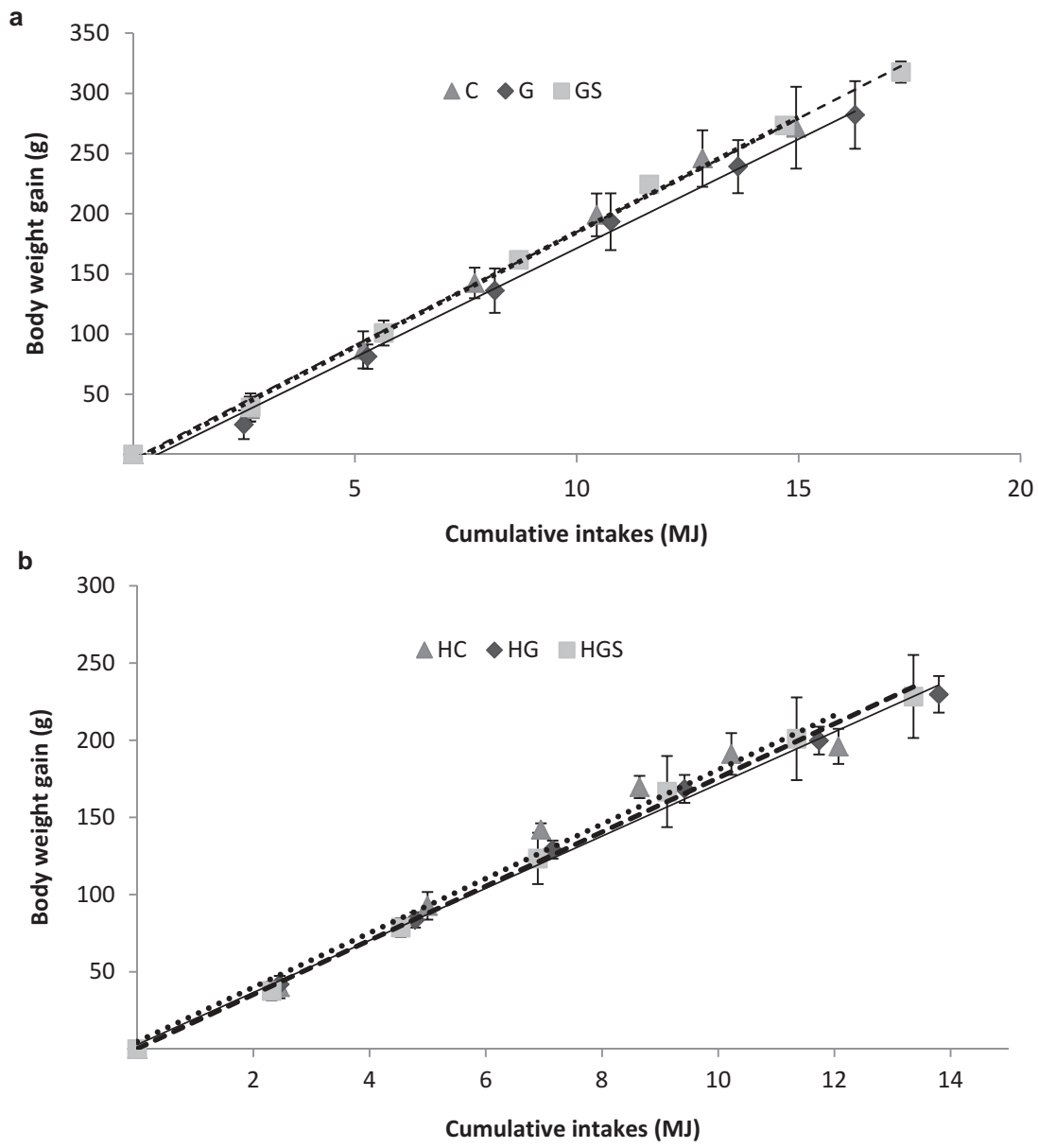

Figure 1. (a) Growth rates (body weight gain (g)/food consumption (MJ)) in rats fed the control, glucomannan- and glucomannan plus spirulina-enriched pork experimental diets. $Y=$ (slope with their standard error) $X+$ (intercept with their standard error). Where $Y$ is the body weight gain and $X$ is the food consumption. Control-RP $(C): Y=(19.07 \pm 3.38) X+(-5.94 \pm 0.001) ; r^{2}=0.996$ $(p<0.001) ; \beta=0.998$. Glucomannan-RP $(\mathrm{G}): \mathrm{Y}=(18.13 \pm 3.22) \mathrm{X}+(-9.94 \pm 0.001) ; r^{2}=0.995(p<0.001) ; \beta=0.990$. Glucomannan plus spirulina-RP: $Y=(18.86 \pm 1.76) X+(-3.73 \pm 0.001) ; r^{2}=0.998(p<0.001) ; \beta=0.998$. Mean values were significantly different (ANCOVA test) for C vs. G. C vs. GS. and G vs. GS (all $p<0.05$ ). (b) Growth rates in rats fed the control. Glucomannan- and glucomannan plus spirulina-RP experimental diets with supplementary cholesterol. Hypercholesterolemic control-RP (HC): $Y=(17.62 \pm 3.28) X+(4.69 \pm 0.001) ; r^{2}=0.973(p<0.001) ; \beta=0.987$. Hypercholesterolemic glucomannan-RP (HG): $Y=(16.88 \pm 2.01) X+(2.77 \pm 0.001) ; r^{2}=0.997(p<0.001) ; \beta=0.995$. Hypercholesterolemic glucomannan plus spirulina-RP (HGS): $Y=(17.54 \pm 2.94) X+(0.15 \pm 0.001) ; r^{2}=0.998(p<0.001) ; \beta=0.989$. Mean values were significantly different (ANCOVA test) for HC vs. HG and HC vs. HGS (both $p<0.05$ ). RP: restructured pork.

significantly lower in $\mathrm{HC}$ and $\mathrm{HG}$ vs. $\mathrm{C}$ and in $\mathrm{G}$ livers, and in HGS vs. HC groups. Docosahexaenoic acid (C22:6n3) percentages were lower in $\mathrm{HC}, \mathrm{HG}$, HGS vs. C, G, GS livers.

SFA percentages were lower in HC and HGS $v s$. their $\mathrm{C}$ and GS counterparts' livers and in HC vs. HG and HGS livers. MUFA percentages were higher in HC, HG, HGS vs. C, G, GS rats. The PUFA percentages were significantly lower in HC, HG and HGS vs. C, G, and GS.

Information regarding estimated desaturase and desaturase-elongase activity is shown in Table 3 . The C20:4 n-6/C18:2 n-6 ratio and delta-5-desaturase activity were significantly affected by the type of $\mathrm{RP}^{*}$ cholesterol interaction. None of the estimated activities were affected by $2 \mathrm{RP}$ effects; however, the cholesterol effect affected all activities except that of delta-6-desaturase. The $\mathrm{C} 22: 6 \mathrm{n} 3 / \mathrm{C} 18: 3 \mathrm{n} 3$ ratio was lower in $\mathrm{HC}$, HG and HGS vs. C, G, GS livers. The C20:4n6/C18:2n6 ratio was lower in HG and HGS vs. G and GS livers and in HG and HGS vs. HC livers. The C18:1n9/C18:0 ratio was higher in $\mathrm{HG} v$ s. G livers while SCD activity was higher in HC and HG vs. C and GS livers and in $\mathrm{HC}$ than in HG livers. Delta-5-desaturase activity was higher in G and GS livers vs. C livers.

Results in Table 4 show that liver redox indices (RI), GSH and GSSG were unaffected by the different diets. 
Table 1. Effects of glucomannan or glucomannan plus spirulina-RP on final weight, liver fat, total cholesterol and glucose of cholesterol-fed fa/fa rats.

\begin{tabular}{|c|c|c|c|c|c|c|c|}
\hline & \multirow[b]{2}{*}{$\begin{array}{l}\text { Cholesterol } \\
\text { addition }\end{array}$} & \multirow[b]{2}{*}{$\begin{array}{c}\text { Control RP (C/ } \\
\mathrm{HC})\end{array}$} & \multirow[b]{2}{*}{$\begin{array}{l}\text { Glucomanan-RP } \\
\text { (G/HG) }\end{array}$} & \multirow[b]{2}{*}{$\begin{array}{l}\text { Glucomanan plus Spirulina-RP } \\
\text { (GS/HGS) }\end{array}$} & \multicolumn{3}{|c|}{ ANOVA } \\
\hline & & & & & $\begin{array}{c}\mathrm{RP} \\
\text { effect }\end{array}$ & $\begin{array}{l}\text { Cholesterol } \\
\text { effect }\end{array}$ & $\begin{array}{l}\mathrm{RP}^{*} \text { Cholesterol } \\
\text { interaction }\end{array}$ \\
\hline \multirow[t]{2}{*}{ Weight gain (g) } & No & $285.6 \pm 39.1^{a}$ & $314.7 \pm 28.5^{\mathrm{ab}}$ & $349.4 \pm 11.7^{b}$ & 0.002 & $<0.001$ & 0.60 \\
\hline & Yes & $210 \pm 23.3^{* *}$ & $240.3 \pm 17.9 * * *$ & $250.7 \pm 43.0^{* *}$ & & & \\
\hline \multirow{2}{*}{$\begin{array}{l}\text { Feed conversion } \\
\text { ratio }^{1}\end{array}$} & No & $0.23 \pm 0.02$ & $0.25 \pm 0.01$ & $0.26 \pm 0.01$ & 0.005 & $<0.001$ & 0.47 \\
\hline & Yes & $0.20 \pm 0.02^{*}$ & $0.21 \pm 0.02^{* * *}$ & $0.23 \pm 0.04$ & & & \\
\hline \multirow[t]{2}{*}{ Feed intake (g) } & No & $1239 \pm 69.9^{a}$ & $1279 \pm 91.0^{\mathrm{ab}}$ & $1344 \pm 39.7^{b}$ & $<0.001$ & $<0.001$ & 0.005 \\
\hline & Yes & $1058 \pm 59.7^{\mathrm{a}^{* * *}}$ & $1129 \pm 80.4^{b^{*}}$ & $1089 \pm 32.1^{\mathrm{a}^{* * *}}$ & & & \\
\hline \multirow[t]{2}{*}{ Liver weight (g) } & No & $11.8 \pm 1.2$ & $13.4 \pm 2.8$ & $15.0 \pm 0.7$ & 0.55 & $<0.001$ & 0.11 \\
\hline & Yes & $28.2 \pm 3.2^{* * *}$ & $29.7 \pm 2.4^{* * *}$ & $25.5 \pm 6.7^{* *}$ & & & \\
\hline \multirow{2}{*}{ Liver fat (\%) } & No & $13.6 \pm 7.6$ & $10.2 \pm 3.1$ & $11.17 \pm 2.9$ & 0.52 & $<0.001$ & 0.14 \\
\hline & Yes & $19.4 \pm 5.2$ & $24.4 \pm 5.8^{*}$ & $27.9 \pm 6.4^{*}$ & & & \\
\hline \multirow{2}{*}{$\begin{array}{l}\text { Liver cholesterol } \\
\quad(\mathrm{mmol} / \mathrm{g})\end{array}$} & No & $7.9 \pm 3.6$ & $12.5 \pm 4.2$ & $12.6 \pm 3.7$ & 0.073 & 0.015 & 0.71 \\
\hline & Yes & $12.9 \pm 4.3$ & $15.5 \pm 4.3$ & $19.3 \pm 6.3$ & & & \\
\hline \multirow{2}{*}{$\begin{array}{l}\text { Plasma cholesterol } \\
\quad(\mathrm{mmol} / \mathrm{L})\end{array}$} & No & $4.4 \pm 0.9$ & $4.3 \pm 0.4$ & $4.7 \pm 0.9$ & $<0.001$ & $<0.001$ & $<0.001$ \\
\hline & Yes & $25.6 \pm 8.4^{\mathrm{a}^{* * *}}$ & $10.8 \pm 2.1^{b^{* * *}}$ & $6.1 \pm 3.6^{b}$ & & & \\
\hline \multirow{2}{*}{$\begin{array}{l}\text { Plasma glucose } \\
\qquad(\mathrm{mmol} / \mathrm{L})\end{array}$} & No & $19.3 \pm 1.9$ & $19.7 \pm 4.1$ & $18.9 \pm 3.4$ & 0.99 & $<0.001$ & 0.83 \\
\hline & Yes & $12.8 \pm 3.5^{* *}$ & $12.4 \pm 7.9$ & $13.8 \pm 4.8$ & & & \\
\hline \multirow{2}{*}{$\begin{array}{l}\text { Plasma triglycerides } \\
\text { (mmol/L) }\end{array}$} & No & $1.69 \pm 1.08$ & $1.75 \pm 0.77$ & $1.74 \pm 0.47$ & 0.055 & 0.12 & 0.022 \\
\hline & Yes & $2.95 \pm 0.79^{a^{*}}$ & $1.84 \pm 0.27^{b}$ & $0.96 \pm 0.41^{c^{*}}$ & & & \\
\hline \multirow[t]{2}{*}{ TyG index ${ }^{2}$} & No & $10.0 \pm 0.6$ & $10.1 \pm 0.4$ & $10.1 \pm 0.3$ & 0.085 & 0.025 & 0.026 \\
\hline & Yes & $10.3 \pm 0.3^{\mathrm{a}}$ & $9.7 \pm 0.5^{\mathrm{ab}}$ & $9.1 \pm 0.7^{\mathrm{b}^{*}}$ & & & \\
\hline \multirow{2}{*}{ Ldlr expression } & No & $100.0 \pm 44.8$ & $110.0 \pm 78.5$ & $92.0 \pm 28.8$ & 0.56 & $<0.001$ & 0.52 \\
\hline & Yes & $28.7 \pm 23.0^{\mathrm{a}^{* *}}$ & $0.9 \pm 0.7^{b^{* *}}$ & $0.2 \pm 0.2^{\mathrm{b}^{* * *}}$ & & & \\
\hline
\end{tabular}

Values (mean $\pm S D, n=6$ ) in the same row bearing different letters were significantly different ( $p<0.05$; Bonferroni or T2-Tamhane tests). Values for the same diet but with different cholesterol content bearing asterisks were significantly different $\left({ }^{*} p<0.05,{ }^{* *} p<0.01,{ }^{* * *} p<0.001\right)$. ${ }^{1}$ Feed conversion ratio $=$ weight gain $\left(\mathrm{g} /\right.$ day)/food intake $\left(\mathrm{g} /\right.$ day); ${ }^{2} \mathrm{TyG}$ index: $\mathrm{Ln}$ (fasting triglycerides $(\mathrm{mg} / \mathrm{dL}) \mathrm{x}$ fasting glucose $\left.(\mathrm{mg} / \mathrm{dL}) / 2\right)$. C/CH, control-RP with or without added cholesterol; G/HG, glucomannan-RP with or without added cholesterol; GS/HGS, glucomannan plus spirulina-RP with or without added cholesterol.

Table 5 shows results of antioxidant enzyme activities and expressions. Enzyme activities were not significantly modified by the RP-type factor or the RPtype and cholesterol. GPx and CAT activity tended to low with cholesterol feeding. Western blot (WB) (Figure 2) shows that both factors and their interaction relevantly and significantly affect enzyme levels. The protein level (Western-blot) was significantly higher in all tested enzymes for $\mathrm{HC} v s$. C rat livers. A significant decrease in CAT and SOD levels was observed in HG and HGS vs. G and GS rats. Spirulina addition significantly increase GPx and GR protein levels when compared HGS vs. GS.

Only CAT expression was significantly affected by RPtype and cholesterol interaction. RP-type significantly affected Mn-SOD and CAT expressions. Cholesterol significantly affected all enzyme expression. $\mathrm{Cu} / \mathrm{Zn}-\mathrm{SOD}$ expression in HGS $v s$. HC rats; Mn-SOD expression in GS $v s$. C and in HGS vs. HC rats were significantly lower; CAT expression in GS vs. C animals; and the GR and GPx expressions in HGS vs. HC rats. Glucomannan plus spirulina vs. glucomannan affected the CAT and GPx expression in HGS $v s$. HG rats.

$\mathrm{Cu} / \mathrm{Zn}$-SOD, CAT, GR and GPx were significantly lower in HC, HG and HGS vs. C, G and GS rats. MnSOD expression was significantly higher in $\mathrm{HC} v s$. C rats $(p<0.01)$.
Several significant correlations were found. Liver weight and the hepatosomatic index correlated negatively and significantly with $L d l r$ expression, $\mathrm{Cu} / \mathrm{Zn}$ SOD, CAT, GPx and GR expression and WB levels, delta-6-elongase-desaturase and delta-5-desaturase activities (all $p<0.001$ ) and GPx activity (at least $p<0.01$ ) while a positive correlation was found with SCD and oleoyl-CoA reductase activities and Mn-SOD (at least $p<0.01$ ).

\section{Discussion}

This study shows for the first time that RP and cholesterol modified liver fatty acid profile and antioxidant enzyme activities, levels and expressions and $L d l r$ expression in $\mathrm{fa} / \mathrm{fa}$ rats. These results were interrelated and also highly dependent on body weight. Zucker fa/ fa rats became severely obese, their daily food intake was very high and they exhibited hypercholesterolemia as described by other others, very high daily intake and hypercholesterolemia in concurrence with other authors [35]. Surprisingly, G and GS included in RP did not have a satiating effect as has been suggested by other authors in relation to Konjac glucomannan $[18,36]$. In fact, comparison of slopes shows that for each kJ consumed, G and GS animals gained 0.002- 
Table 2. Effects of glucomannan or glucomannan plus spirulina-RP on liver fatty acid profile ( $\mathrm{g} / 100 \mathrm{~g}$ of methyl ester) of cholesterolfed fa/fa rats.

\begin{tabular}{|c|c|c|c|c|c|c|c|}
\hline & \multirow[b]{2}{*}{$\begin{array}{l}\text { Cholesterol } \\
\text { addition }\end{array}$} & \multirow[b]{2}{*}{$\begin{array}{c}\text { Control RP (C/ } \\
\mathrm{HC})\end{array}$} & \multirow[b]{2}{*}{$\begin{array}{l}\text { Glucomannan-RP } \\
\text { (G/HG) }\end{array}$} & \multirow[b]{2}{*}{$\begin{array}{l}\text { Glucomannan plus Spirulin-RP } \\
\text { (GS/HGS) }\end{array}$} & \multicolumn{3}{|c|}{ ANOVA } \\
\hline & & & & & $\begin{array}{c}\mathrm{RP} \\
\text { effect }\end{array}$ & $\begin{array}{l}\text { Cholesterol } \\
\text { effect }\end{array}$ & $\begin{array}{l}\mathrm{RP} * \text { Cholesterol } \\
\text { interaction }\end{array}$ \\
\hline \multirow[t]{2}{*}{ Myristic (C14:0) } & No & $1.32 \pm 0.53$ & $1.51 \pm 0.39$ & $1.73 \pm 0.67$ & 0.41 & 0.28 & 0.71 \\
\hline & Yes & $1.22 \pm 0.08$ & $1.44 \pm 0.20$ & $1.34 \pm 0.30$ & & & \\
\hline \multirow[t]{2}{*}{ Palmitic (C16:0) } & No & $16.31 \pm 1.31$ & $19.05 \pm 4.60$ & $17.40 \pm 3.22$ & 0.059 & 0.010 & 0.75 \\
\hline & Yes & $12.45 \pm 2.38^{\mathrm{a}^{*}}$ & $16.91 \pm 3.07^{b}$ & $13.17 \pm 1.50^{\mathrm{a}^{*}}$ & & & \\
\hline \multirow[t]{2}{*}{ Palmitoleic (C16:1) } & No & $20.40 \pm 0.25$ & $19.01 \pm 3.27$ & $20.78 \pm 1.29$ & 0.57 & 0.13 & 0.88 \\
\hline & Yes & $22.67 \pm 2.06$ & $22.48 \pm 2.35$ & $23.30 \pm 3.66$ & & & \\
\hline \multirow[t]{2}{*}{ Stearic (C18:0) } & No & $7.10 \pm 1.29^{a}$ & $7.07 \pm 1.19^{a}$ & $9.92 \pm 1.68^{b}$ & 0.026 & 0.037 & 0.25 \\
\hline & Yes & $6.32 \pm 0.73$ & $6.67 \pm 0.85$ & $7.27 \pm 2.11^{* *}$ & & & \\
\hline \multirow[t]{2}{*}{ Oleic (C18:1n9) } & No & $31.96 \pm 2.03^{a b}$ & $32.61 \pm 1.64^{a}$ & $29.26 \pm 2.40^{b}$ & 0.94 & $<0.001$ & 0.088 \\
\hline & Yes & $38.50 \pm 0.59^{* *}$ & $38.62 \pm 0.74^{* * *}$ & $41.12 \pm 5.60^{* *}$ & & & \\
\hline \multirow[t]{2}{*}{ Linoleic (C18:2n6) } & No & $6.26 \pm 1.31^{\mathrm{a}}$ & $4.90 \pm 0.35^{b}$ & $4.89 \pm 0.44^{b}$ & 0.025 & 0.25 & 0.74 \\
\hline & Yes & $6.29 \pm 0.25$ & $5.45 \pm 0.84$ & $5.51 \pm 1.16$ & & & \\
\hline \multirow[t]{2}{*}{ Y-linolenic (C18:3n6) } & No & $0.21 \pm 0.04$ & $0.13 \pm 0.04$ & $0.22 \pm 0.08$ & 0.52 & 0.55 & 0.57 \\
\hline & Yes & $0.17 \pm 0.08$ & $0.21 \pm 0.07^{* *}$ & $0.25 \pm 0.22$ & & & \\
\hline \multirow[t]{2}{*}{ Eicosenoic (C20:1) } & No & $0.23 \pm 0.10$ & $0.19 \pm 0.06$ & $0.26 \pm 0.22$ & 0.43 & 0.50 & 0.86 \\
\hline & Yes & $0.39 \pm 0.10^{*}$ & $0.29 \pm 0.15$ & $0.44 \pm 0.29$ & & & \\
\hline \multirow[t]{2}{*}{ Linolenic (C18:3n3) } & No & $0.27 \pm 0.05$ & $0.21 \pm 0.03$ & $0.26 \pm 0.17$ & 0.041 & 0.020 & 0.43 \\
\hline & Yes & $0.41 \pm 0.05^{\mathrm{a}^{* *}}$ & $0.28 \pm 0.05^{\mathrm{b}^{*}}$ & $0.46 \pm 0.11^{a}$ & & & \\
\hline \multirow{2}{*}{$\begin{array}{l}\text { Eicosatrienoic } \\
\qquad(C 20: 3 n 6)\end{array}$} & No & $0.62 \pm 0.12^{\mathrm{a}}$ & $0.36 \pm 0.14^{b}$ & $0.36 \pm 0.14^{b}$ & 0.030 & 0.22 & 0.50 \\
\hline & Yes & $0.64 \pm 0.16^{a}$ & $0.52 \pm 0.11^{\mathrm{ab}}$ & $0.39 \pm 0.11^{b}$ & & & \\
\hline \multirow{2}{*}{$\begin{array}{l}\text { Eicosatetraenoic } \\
\quad(C 20: 4 n 6)\end{array}$} & No & $9.78 \pm 0.76$ & $9.56 \pm 1.17$ & $9.25 \pm 0.76$ & 0.001 & $<0.001$ & 0.010 \\
\hline & Yes & $7.97 \pm 0.84^{\mathrm{a}^{*}}$ & $5.16 \pm 0.24^{b^{* *}}$ & $5.02 \pm 0.94^{b^{* * *}}$ & & & \\
\hline \multirow{2}{*}{$\begin{array}{l}\text { Eicosapentaenoic } \\
\text { C20:5n3 }\end{array}$} & No & $2.11 \pm 0.82$ & $2.23 \pm 0.49$ & $2.75 \pm 0.83$ & 0.79 & $<0.001$ & 0.098 \\
\hline & Yes & $1.06 \pm 0.22^{a^{*}}$ & $0.61 \pm 0.37^{\mathrm{ab}^{* *}}$ & $0.42 \pm 0.29^{b}$ & & & \\
\hline \multirow{2}{*}{$\begin{array}{l}\text { Docosahexaenoic } \\
\text { (C22:6n3) }\end{array}$} & No & $3.45 \pm 0.40$ & $3.17 \pm 0.84$ & $2.92 \pm 0.91$ & 0.18 & $<0.001$ & 0.89 \\
\hline & Yes & $1.91 \pm 0.44^{* *}$ & $1.35 \pm 0.22^{* *}$ & $1.32 \pm 0.42^{*}$ & & & \\
\hline \multirow{2}{*}{$\begin{array}{l}\text { Saturated Fatty } \\
\text { Acids }\end{array}$} & No & $24.72 \pm 1.53$ & $27.63 \pm 4.35$ & $29.05 \pm 3.67$ & 0.031 & $<0.001$ & 0.29 \\
\hline & Yes & $19.99 \pm 2.18^{\mathrm{a}^{*}}$ & $25.02 \pm 2.59^{b}$ & $21.77 \pm 1.75^{\mathrm{b}^{*}}$ & & & \\
\hline \multirow{2}{*}{$\begin{array}{l}\text { Monosaturated Fatty } \\
\text { Acids }\end{array}$} & No & $52.58 \pm 1.85$ & $51.81 \pm 2.66$ & $50.30 \pm 2.57$ & 0.72 & $<0.001$ & 0.061 \\
\hline & Yes & $61.56 \pm 2.49^{a^{* * *}}$ & $64.39 \pm 2.23^{b^{* *}}$ & $64.86 \pm 2.46^{b^{* * *}}$ & & & \\
\hline \multirow{2}{*}{$\begin{array}{l}\text { Polyunsaturated } \\
\text { Fatty Acids }\end{array}$} & No & $22.70 \pm 0.69$ & $20.55 \pm 2.35$ & $20.65 \pm 2.83$ & 0.003 & $<0.001$ & 0.279 \\
\hline & Yes & $18.45 \pm 0.92^{* * *}$ & $13.59 \pm 0.56^{* * *}$ & $13.37 \pm 3.02^{* *}$ & & & \\
\hline
\end{tabular}

Values (mean $\pm S D, n=6$ ) in the same row bearing different letters were significantly different $(p<0.05$; Bonferroni or T2-Tamhane tests). Values for the same diet but with different cholesterol content bearing asterisks were significantly different $\left({ }^{*} p<0.05,{ }^{* *} p<0.01\right.$, $\left.{ }^{* * *} p<0.001\right)$. C/CH, control-RP with or without added cholesterol; G/HG, glucomannan-RP with or without added cholesterol; GS/HGS, glucomannan plus spirulina-RP with or without added cholesterol.

Table 3. Effects of glucomannan or glucomannan plus spirulina-RP on liver fatty acid ratios (g/100 g of methyl ester) of cholesterolfed $\mathrm{fa} / \mathrm{fa}$ rats.

\begin{tabular}{|c|c|c|c|c|c|c|c|}
\hline & \multirow[b]{2}{*}{$\begin{array}{l}\text { Cholesterol } \\
\text { addition }\end{array}$} & \multirow[b]{2}{*}{$\begin{array}{c}\text { Control RP (C/ } \\
\mathrm{HC})\end{array}$} & \multirow[b]{2}{*}{$\begin{array}{c}\text { Glucomannan-RP } \\
\text { (G/HG) }\end{array}$} & \multirow[b]{2}{*}{$\begin{array}{l}\text { Glucomannan plus Spirulin-RP } \\
\text { (GS/HGS) }\end{array}$} & \multicolumn{3}{|c|}{ ANOVA } \\
\hline & & & & & $\begin{array}{l}\mathrm{RP} \\
\text { effect }\end{array}$ & $\begin{array}{l}\text { Cholesterol } \\
\text { effect }\end{array}$ & $\begin{array}{l}\mathrm{RP}^{*} \text { Cholesterol } \\
\text { interaction }\end{array}$ \\
\hline $\begin{array}{l}\mathrm{C} 22: 6 \mathrm{n} 3 / \mathrm{C} 18: 3 \mathrm{n} 3 \\
\text { ratio }\end{array}$ & $\begin{array}{l}\text { No } \\
\text { Yes }\end{array}$ & $\begin{aligned} 12.99 & \pm 2.91 \\
4.73 & \pm 1.52^{\mathrm{a}^{* *}}\end{aligned}$ & $\begin{aligned} 15.21 & \pm 2.27 \\
5.05 & \pm 1.89^{\mathrm{a}^{* * *}}\end{aligned}$ & $\begin{aligned} 12.47 & \pm 3.43 \\
2.85 & \pm 0.47^{b^{* * *}}\end{aligned}$ & 0.13 & $<0.001$ & 0.70 \\
\hline $\begin{array}{l}\mathrm{C} 20: 4 \mathrm{n} 6 / \mathrm{C} 18: 2 \mathrm{n} 6 \\
\text { ratio }\end{array}$ & $\begin{array}{l}\text { No } \\
\text { Yes }\end{array}$ & $\begin{array}{l}1.62 \pm 0.42 \\
1.27 \pm 0.17^{\mathrm{a}}\end{array}$ & $\begin{array}{l}1.97 \pm 0.32 \\
0.96 \pm 0.15^{b^{* * *}}\end{array}$ & $\begin{array}{l}1.90 \pm 0.22 \\
0.92 \pm 0.09^{b^{* * *}}\end{array}$ & 0.91 & $<0.001$ & 0.030 \\
\hline $\begin{array}{l}\mathrm{C} 16: 1 \mathrm{n} 7 / \mathrm{C} 16: 0 \\
\quad \text { ratio }\end{array}$ & $\begin{array}{l}\text { No } \\
\text { Yes }\end{array}$ & $\begin{array}{l}1.26 \pm 0.10 \\
1.90 \pm 0.38^{\mathrm{a} *}\end{array}$ & $\begin{array}{l}1.08 \pm 0.43 \\
1.38 \pm 0.27^{b}\end{array}$ & $\begin{array}{l}1.23 \pm 0.24 \\
1.77 \pm 0.20^{\mathrm{ab}^{*}}\end{array}$ & 0.15 & 0.002 & 0.63 \\
\hline $\begin{array}{l}\mathrm{C} 18: 1 \mathrm{n} 9 / \mathrm{C} 18: 0 \\
\text { ratio }\end{array}$ & $\begin{array}{l}\text { No } \\
\text { Yes }\end{array}$ & $\begin{array}{l}4.66 \pm 1.11 \\
6.16 \pm 0.73\end{array}$ & $\begin{array}{l}4.73 \pm 0.98 \\
5.86 \pm 0.82^{*}\end{array}$ & $\begin{array}{l}3.04 \pm 0.73 \\
5.99 \pm 1.65\end{array}$ & 0.21 & $<0.001$ & 0.22 \\
\hline $\begin{array}{l}\text { Delta-5- } \\
\text { desaturase }\end{array}$ & $\begin{array}{l}\text { No } \\
\text { Yes }\end{array}$ & $\begin{array}{l}16.40 \pm 3.30 a \\
13.33 \pm 5.08\end{array}$ & $\begin{array}{l}20.61 \pm 5.79 a b \\
10.30 \pm 3.03^{* *}\end{array}$ & $\begin{array}{l}28.22 \pm 5.14 a \\
13.63 \pm 3.53^{* *}\end{array}$ & 0.10 & $<0.001$ & 0.046 \\
\hline $\begin{array}{l}\text { Delta-6- } \\
\text { desaturase }\end{array}$ & $\begin{array}{l}\text { No } \\
\text { Yes }\end{array}$ & $\begin{array}{l}0.034 \pm 0.010 \\
0.027 \pm 0.012\end{array}$ & $\begin{array}{l}0.026 \pm 0.010 \\
0.040 \pm 0.016\end{array}$ & $\begin{array}{l}0.044 \pm 0.014 \\
0.041 \pm 0.028\end{array}$ & 0.33 & 0.85 & 0.45 \\
\hline
\end{tabular}

Values (mean $\pm S D, n=6$ ) in the same row bearing different letters were significantly different ( $p<0.05$; Bonferroni or T2-Tamhane tests). Values for the same diet but with different cholesterol content bearing asterisks were significantly different $\left({ }^{*} p<0.05,{ }^{* *} p<0.01,{ }^{* * *} p<0.001\right)$.

Stearoyl-CoA-desaturase, C16:1 n-7/C16:0; Delta-5-desaturase: C20:4 n-6/C20:3 n-6; Delta-6- desaturase: C18:3 n-6/C18:2 n-6. C/CH, control-RP with or without added cholesterol; G/HG, glucomannan-RP with or without added cholesterol; GS/HGS, glucomannan plus spirulina-RP with or without added cholesterol.

$0.005 \mathrm{~g}$ less than $\mathrm{C}$ rats. The stomach is known to produce ghrelin and leptin, two important food intake controllers. However, as fa/fa rats are leptin-resistant [37], any expected mechanism linking leptin and satiation has to be studied carefully. In addition, fructose and saturated fatty acids, two major compounds of the assayed diets, modify the production response of both gastric hormones [38]. In agreement with Beynen 
Table 4. Effects of glucomannan or glucomannan plus spirulina-RP on liver redox ratio, GSH and GSSG of cholesterol-fed fa/fa rats.

\begin{tabular}{|c|c|c|c|c|c|c|c|}
\hline & \multirow[b]{2}{*}{$\begin{array}{l}\text { Cholesterol } \\
\text { addition }\end{array}$} & \multirow[b]{2}{*}{$\begin{array}{l}\text { Control RP } \\
(\mathrm{C} / \mathrm{HC})\end{array}$} & \multirow[b]{2}{*}{$\begin{array}{l}\text { Glucomannan-RP } \\
\text { (G/HG) }\end{array}$} & \multirow[b]{2}{*}{$\begin{array}{c}\text { Glucomannan plus Spirulina- } \\
\text { RP (GS/HGS) }\end{array}$} & \multicolumn{3}{|c|}{ ANOVA } \\
\hline & & & & & $\begin{array}{c}\mathrm{RP} \\
\text { effect }\end{array}$ & $\begin{array}{l}\text { Cholesterol } \\
\text { effect }\end{array}$ & $\begin{array}{l}\mathrm{RP}^{*} \text { Cholesterol } \\
\text { interaction }\end{array}$ \\
\hline \multirow{4}{*}{$\begin{array}{l}\text { GSH } \\
(\mu \mathrm{g} / \mathrm{mg} \text { tissue }) \\
\text { GSSG } \\
(\mu \mathrm{g} / \mathrm{mg} \text { tissue })\end{array}$} & No & $0.60 \pm 0.25$ & $0.61 \pm 0.22$ & $0.52 \pm 0.19$ & 0.98 & 0.14 & 0.830 \\
\hline & Yes & $0.50 \pm 0.14$ & $0.47 \pm 0.12$ & $0.52 \pm 0.18$ & & & \\
\hline & No & $0.63 \pm 0.22$ & $0.55 \pm 0.03$ & $0.62 \pm 0.18$ & 0.70 & 0.27 & 0.875 \\
\hline & Yes & $0.54 \pm 0.06$ & $0.51 \pm 0.07$ & $0.57 \pm 0.15$ & & & \\
\hline \multirow[t]{2}{*}{ RI } & No & $0.48 \pm 0.09$ & $0.51 \pm 0.10$ & $0.45 \pm 0.06$ & 0.90 & 0.53 & 0.817 \\
\hline & Yes & $0.47 \pm 0.10$ & $0.47 \pm 0.09$ & $0.48 \pm 0.11$ & & & \\
\hline
\end{tabular}

Values (mean $\pm S D, n=6$ ) in the same row bearing different letters were significantly different $(p<0.05$; Bonferroni or T2-Tamhane tests). Values for the same diet but with different cholesterol content bearing asterisks were significantly different $\left({ }^{*} p<0.05,{ }^{* *} p<0.01,{ }^{* * *} p<0.001\right)$. GSH, reduced glutathione; GSSG, oxidized glutathione; Rl, redox index; RI = [GSH/(GSH+GSSG)]. C/CH, control-RP with or without added cholesterol; G/HG, glucomannanRP with or without added cholesterol; GS/HGS, glucomannan plus spirulina-RP with or without added cholesterol.

Table 5. Effects of glucomannan or glucomannan plus spirulina-RP on liver antioxidant enzymes of cholesterol-fed fa/fa rats.

\begin{tabular}{|c|c|c|c|c|c|c|c|}
\hline & \multirow[b]{2}{*}{$\begin{array}{l}\text { Cholesterol } \\
\text { addition }\end{array}$} & \multirow[b]{2}{*}{ Control RP (C/HC) } & \multirow[b]{2}{*}{$\begin{array}{c}\text { Glucomannan-RP } \\
(\mathrm{G} / \mathrm{HG})\end{array}$} & \multirow[b]{2}{*}{$\begin{array}{l}\text { Glucomannan plus } \\
\text { Spirulina-RP (GS/HGS) }\end{array}$} & \multicolumn{3}{|c|}{ ANOVA } \\
\hline & & & & & $\begin{array}{c}\text { RP } \\
\text { effect }\end{array}$ & $\begin{array}{c}\text { Cholesterol } \\
\text { effect }\end{array}$ & $\begin{array}{l}\mathrm{RP}^{*} \text { Cholestero } \\
\text { interaction }\end{array}$ \\
\hline Cu,Zn-SOD Expression (\% vs. C) & $\begin{array}{l}\text { No } \\
\text { Yes }\end{array}$ & $\begin{aligned} 100.0 & \pm 19.04 \\
5.78 & \pm 3.27^{\text {a**** }}\end{aligned}$ & $\begin{aligned} 121.11 & \pm 30.47 \\
5.14 & \pm 4.07 \mathrm{ab}_{* *}\end{aligned}$ & $\begin{aligned} 95.32 & \pm 45.94 \\
0.35 & \pm 0.21^{b_{* * *}}\end{aligned}$ & 0.26 & $<0.001$ & 0.41 \\
\hline Mn-SOD Expression (\%vs.C) & $\begin{array}{l}\text { No } \\
\text { Yes }\end{array}$ & $\begin{array}{l}100.0 \pm 18.67^{a} \\
183.2 \pm 46.63^{a * *}\end{array}$ & $\begin{array}{l}44.30 \pm 15.03^{b} \\
92.78 \pm 61.20^{b}\end{array}$ & $\begin{array}{l}52.91 \pm 27.71^{b} \\
67.11 \pm 10.42^{b}\end{array}$ & $<0.001$ & 0.001 & 0.122 \\
\hline SOD Activity (U/mg de protein) & $\begin{array}{l}\text { No } \\
\text { Yes }\end{array}$ & $\begin{array}{l}0.14 \pm 0.08 \\
0.16 \pm 0.05\end{array}$ & $\begin{array}{l}0.18 \pm 0.08 \\
0.20 \pm 0.06\end{array}$ & $\begin{array}{l}0.16 \pm 0.11 \\
0.16 \pm 0.06\end{array}$ & 0.45 & 0.60 & 0.92 \\
\hline CAT Expression (\%vs. C) & $\begin{array}{l}\text { No } \\
\text { Yes }\end{array}$ & $\begin{array}{l}100.0 \pm 31.63^{\mathrm{a}} \\
10.13 \pm 6.22^{a b_{* * *}}\end{array}$ & $\begin{array}{l}60.28 \pm 16.95^{a b} \\
20.52 \pm 9.02^{a * * *}\end{array}$ & $\begin{aligned} 48.78 & \pm 18.02^{\mathrm{b}} \\
3.99 & \pm 1.43^{b_{* * *}}\end{aligned}$ & 0.009 & $<0.001$ & 0.010 \\
\hline CAT Activity (U/mg protein) & $\begin{array}{l}\text { No } \\
\text { Yes }\end{array}$ & $\begin{array}{l}37.54 \pm 7.94 \\
30.33 \pm 7.53\end{array}$ & $\begin{array}{l}33.91 \pm 3.74 \\
30.41 \pm 8.41\end{array}$ & $\begin{array}{l}38.61 \pm 11.82 \\
29.49 \pm 13.51\end{array}$ & 0.87 & 0.061 & 0.79 \\
\hline GPx Expression (\% vs. C) & $\begin{array}{l}\text { No } \\
\text { Yes }\end{array}$ & $\begin{array}{l}100.0 \pm 27.53 \\
23.67 \pm 8.03^{\mathrm{a} * * *}\end{array}$ & $\begin{array}{l}96.45 \pm 38.28 \\
22.69 \pm 10.46^{\mathrm{a} * * *}\end{array}$ & $\begin{aligned} 75.87 & \pm 25.48 \\
7.39 & \pm 3.26^{b_{* * * *}}\end{aligned}$ & 0.085 & $<0.001$ & 0.92 \\
\hline GPx Activity (U/mg protein) & $\begin{array}{l}\text { No } \\
\text { Yes }\end{array}$ & $\begin{array}{r}11952 \pm 5986 \\
7364 \pm 3072\end{array}$ & $\begin{array}{l}9103 \pm 2678 \\
6791 \pm 1545\end{array}$ & $\begin{aligned} 10952 & \pm 3011 \\
7307 & \pm 945\end{aligned}$ & 0.47 & 0.006 & 0.72 \\
\hline GR Expression (\% vs. C) & $\begin{array}{l}\text { No } \\
\text { Yes }\end{array}$ & $\begin{array}{l}100.0 \pm 34.42 \\
31.60 \pm 9.08^{\mathrm{a} * * *}\end{array}$ & $\begin{array}{l}100.5 \pm 27.70 \\
31.14 \pm 15.90^{a * * * *}\end{array}$ & $\begin{array}{l}86.94 \pm 23.05 \\
11.56 \pm 1.37^{\text {b****}}\end{array}$ & 0.14 & $<0.001$ & 0.92 \\
\hline
\end{tabular}

Values (mean $\pm S D, n=6$ ) in the same row bearing different letters were significantly different $(p<0.05$; Bonferroni or T2-Tamhane tests). Values for the same diet but with different cholesterol content bearing asterisks were significantly different $\left({ }^{*} p<0.05, * * p<0.01,{ }^{* * *} p<0.001\right)$. C/CH, control-RP with or without added cholesterol; G/HG, glucomannan-RP with or without added cholesterol; GS/HGS, glucomannan plus spirulina-RP with or without added cholesterol.

et al. [39], lower feed intake and growth were found in cholesterol-fed rats. As a result of this reduction, lower values of plasma glucose were found in the HC group. The higher plasma glucose and TyG values clearly suggest that diabetes and insulin resistance was pervasively present in all rat groups [40]. The TyG index was not significantly modified in $\mathrm{HC}$ when compared to $\mathrm{C}$ because of the mathematical proportion of the logarithm. The triglycerides are higher in HC due to cholesterol addition to diet, while glucose is lower because the food intake reduction.

All of the non-cholesterol and cholesterol-fed fa/fa rats were diabetic as their plasma glucose surpassed the cut-off point of $7 \mathrm{mmol} / \mathrm{L}$, diabetes cut-off point for humans [41]. However, the prevalence of hyperglycemia $>11.1 \mathrm{mmol} / \mathrm{L}$ was lower in groups that consumed cholesterol-added diets (50\% in HC; $33 \%$ in HG and $17 \%$ in HGS rats). The presence of glucomannan and spirulina in the cholesterol-fed animals also reduced the TyG index with respect to their counterparts suggesting improvement of insulin resistance as TyG values of 9.1 and 10.3 have been proposed as the median and 95th percentile in patients affected by metabolic syndrome [40]. Rats consuming cholesterolenriched diets showed lower weight gain and growth rates than their non-cholesterol counterparts. In addition, those rats presented lower total adipose tissue mass (data not shown), interestingly a positive significant correlation was found between plasma glucose and growth rate $(r=0.387 ; p=0.024)$ and with total adipose tissue mass $(r=0.397 ; p=0.020)$; explaining why cholesterol-fed animals glucose level improvement.

Data from a previous paper showed that the prevalence of severe cholesterolemia in non-cholesterol fa/fa rats was reduced by G-RP and GS-RP intake. The benefits of consuming G-RP and GS-RP were also much more evident as these meat products strongly limited the hypercholesterolemic effects of dietary cholesterol [42]. However, HG and HGS diets 


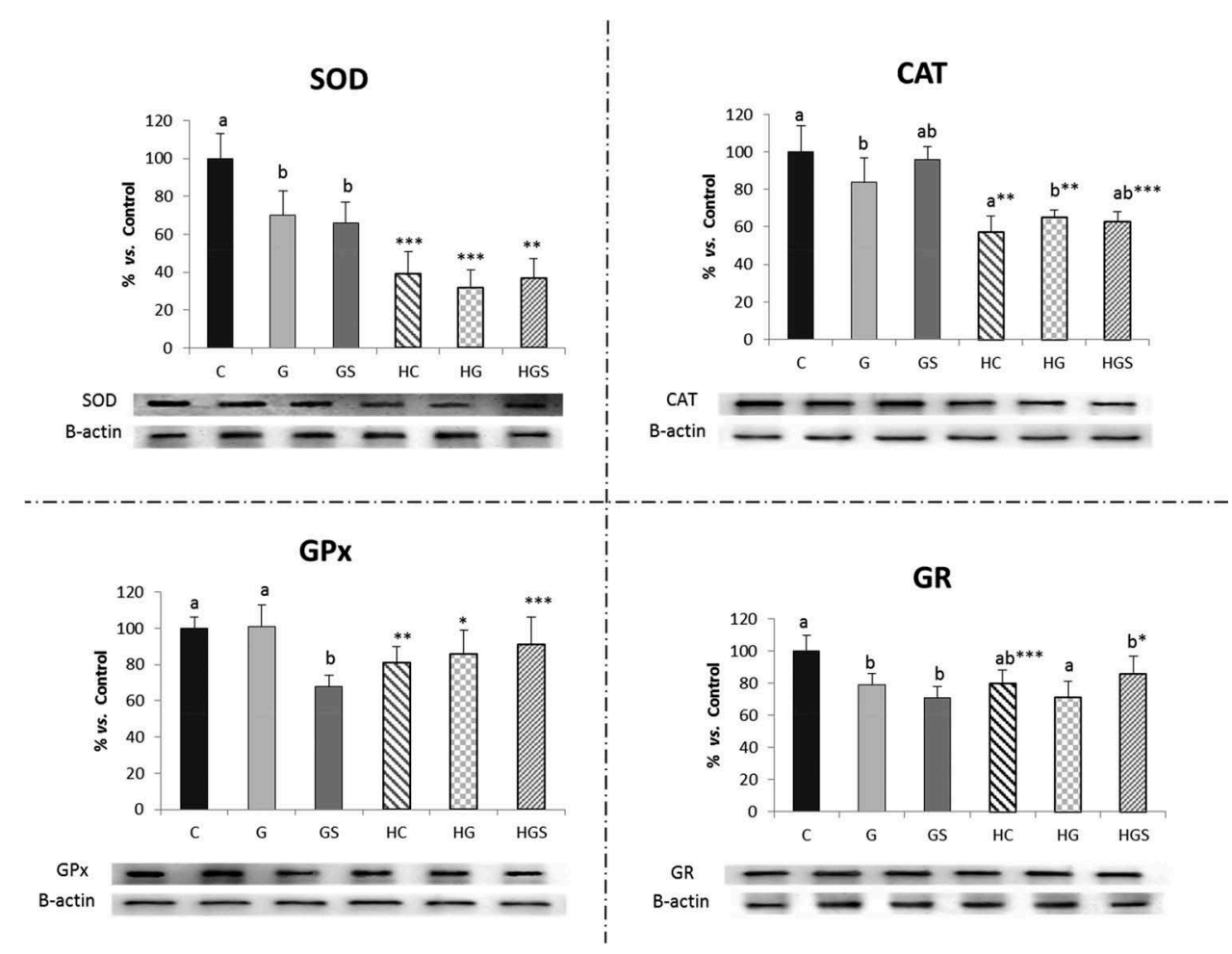

Figure 2. Protein levels of the main antioxidant enzymes measured by Western-blot in rats fed the glucomannan- and glucomannan plus spirulina-enriched pork experimental diets. Mean values and standard deviations $(n=6)$. Statistical comparison between HC vs. C, HG vs. G and HGS vs. GS groups, ${ }^{*}$ indicate significant differences $\left({ }^{*} p<0.05,{ }^{* *} p<0.01,{ }^{* * *} p<0.001\right)$. Bars with different letters indicate significant differences (at least $p<0.05$ ) between $C, G$ and GS or HC, HG and HGS groups. CAT, catalase; SOD, superoxide dismutase; GR, glutathione reductase; GPx, glutathione peroxidase. $\mathrm{C} / \mathrm{CH}$, control-RP with or without added cholesterol; $\mathrm{G} / \mathrm{HG}$, glucomannan-RP with or without added cholesterol; GS/HGS, glucomannan plus spirulina-RP with or without added cholesterol. Results were calculated as percentage relative to control.

unexpectedly blocked $L d l r$ expression, thus the hypocholesterolemic effect of glucomannan or glucomannan plus spirulina appeared clearly unrelated with modifications in the $L d l r$ expression. Therefore it must be accepted that through fat retention by adsorption and/or the seizing of bile salts, glucomannan contributes to reducing the effects of high fat diets [16]. According to our data, $3 \mathrm{~g} / \mathrm{kg}$ of spirulina present in HGS diets improved the hypocholesterolemic response of glucomannan in cholesterol-fed animals [43], probably by seizing bile salts as has been suggested in the case of some polyphenols [44]. Although we are far from knowing the mechanism involved in this expression inhibition, it can be suggested that it prevents additional liver cholesterol uptake (via lipoproteins) and steatosis.

As a consequence of their inner metabolism [33] and diet composition, $\mathrm{C}$ rats presented hypercholesterolemia [45] and have an increased percentage of oleic and palmitoleic acids in the liver in comparison to those reported by Viejo et al. [29] in control Wistar rats fed semisynthetic diets containing casein and olive oil. In addition, cholesterolemia and oleic acid appeared increased in cholesterol fed animals (HC, HG and HGS rats in comparison to C, G and GS rats). According to the ANOVA test the consumption of the hypercholesterolemic agent induced significant decrease on palmitic and steric acids and an increase on palmitoleic and oleic acids, their metabolic products. With respect to the comparison HC vs. C, both palmitic and stearic acid levels tended to decrease while palmitoleic and oleic acids to increase; clearly suggesting that the SCD activity (palmitoleic acid/palmitic acid and oleic acid/stearic acid ratios), a surrogate index of delta-9-desaturase activity, increased in HC vs. C animals. Viejo et al. [29] reported that oleic acid and the oleic/stearic acid ratio increased in the liver of rats fed cholesterol-enriched diets and suggested that this increase occurred in the form of cholesteryl oleate as a mechanism to reduce the free cholesterol pool in the liver, which in turn increases the activity of VLDL and LDL receptors in an attempt to decrease the plasma levels of the atherogenic VLDL and LDL particles.

HC, HG and HGS rats in comparison to C, G and GS rats have lower polyunsaturated fatty acids (total, 
arachidonic acid (AA), eicosapentaenoic acid (EPA) and docosahexaenoic acid (DHA)) while HC and HGS vs. C and GS also presented lower amounts of saturated fatty acid in the liver. In addition, arachidonic/linoleic acid (AA/AL) and docosahexaenoic/linolenic acid (DHA/LL) ratios were lower, suggesting that feeding fa/fa rats with cholesterol enriched experimental diets partially inhibited the delta-6-desaturase-elongase system, known to be responsible for transforming linoleic and linolenic acids into longer and more unsaturated fatty acids of the omega- 6 and omega- 3 families, respectively [20]. Bochenek and Rodgers [46] and Huang et al. [47] have described that delta-6-desaturase-elongase system activity diminishes in the presence of a cholesterol-enriched diet. Very recently, Jacobs et al. [24] suggested that delta-5-desaturase (D5D), delta-6-desaturase (D6D) and stearoyl-CoA desaturase (SCD) activities are related with the incidence of T2DM.

Our results suggest that SCD as liver fat increased due to cholesterol feeding. Elevated SCD activity in liver, estimated from total fatty acids, was positively related to liver fat histologically determined [48]. However, HG diet decreased the SCD activity observed in HC animals. According to [28], the SCD index should be preferably based on defined lipid fraction whereas SCD derived from total hepatic fatty acids should be cautiously interpreted. D5D activity was higher in GS vs. C rats suggesting that GS diet promoted anti-inflammatory properties [49]. In cholesterol fed rats, principally in diet $H G$ and HGS vs. G and HGS, D5D activity decreased suggesting that, although glucomannan has a potent hypocholesterolemic effect, a side inflammatory effect should not be discarded. However, even though D6D was not significantly affected, a tendency to increase was also observed in those animals. The rise in $\mathrm{D} 6 \mathrm{D}$ has been related to an increase in arachidonic acid which is a precursor from eicosanoids that can act as inflammatory mediators [6]. Unpublished histological data clearly suggest that inflammatory focal points were observed in the cholesterol-fa/fa rats.

The decrease in delta-6-desaturase-elongase observed in cholesterol-fed fa/fa rats was greater in HG and HGS animals vs. their $G$ and GS counterparts. It is well known that linoleic and linolenic acids are less oxidizable than arachidonic acid, EPA and DHA. It can be speculated that partial inhibition of the transformation of linolenic acid in EPA and DHA and that of linoleic acid in arachidonic acid, could occur as a protective mechanism to avoid excess of highly peroxidable fatty acids and oxysterol in the liver.
Alterations in the regulation of the redox balance and an increase of reactive oxygen species (ROS) has been reported in animal models of diabetes [50]. The results in Table 4, expressed in $\mu \mathrm{mol} / \mathrm{g}$, showed GSH levels three times lower and GSSG levels three times higher than those reported for Wistar control rats by Bocanegra et al. [51]. The redox index of 0.60 found in the $\mathrm{C}$ group was also much lower than the one reported by Schultz et al. [52] for Wistar rats fed RP. This suggests that Zucker fa/fa rats have a genetic predisposition to develop diabetes, dyslipidemia and low redox index. The pre-existing antioxidant defense deficiency tended to be impaired after cholesterol feeding as reported by others in Wistar rats [51]. In diabetes the enzyme glucose-6-phosphate dehydrogenase (G6PD) is inhibited; therefore, the entire defense mechanism becomes compromised and lower amounts of enzymatic-cofactor NADPH are formed and available [50,53]. This cofactor is essential for GSH regeneration. The consumption of GS and G diets did not provide any change in the liver levels of GSH, GSSG and RI. Also, other studies have proved that dietary components, like fat or cholesterol affect the antioxidant defense in cells [54], leading to unexpected levels of non-enzymatic antioxidants (e.g. glutathione levels) and modifications of the enzymatic pathway. Our group have recently proved that elevated levels of dietary fat lead to high lipid peroxidation indirectly modifying GSH levels and glutathione enzyme activity [55].

In addition, in the groups that consumed cholesterol the RI, GSH and GSSG remained unchanged in relation to their non-cholesterol counterparts. With the exception of SOD, all other enzyme activities studied were negatively affected by cholesterol feeding. However, basal values of CAT activities were much lower while those of GPx were higher in this experiment than in a previous ones [52,56] suggesting that fa/ fa rats address these enzyme activities to reduce the hydroperoxydes coming from PUFA. Once again, the relationship between delta-6-desaturase-enlogase and liver oxidation can be suggested. Our group has found that cholesterol-feeding greatly increased the absorption and bioavailability of iron (unpublished data) which is known to have pro-oxidant effects. Cordero Herrera et al. [57] reported that obese Zucker rats showed increased ROS production but no modification of GR or GPx enzymes with respect to lean Zucker rats.

Interestingly, in cholesterol-fed rats $v s$. non-cholesterol-fed ones, WB and PCR exhibited similar tendencies. The decrease in enzyme WB levels for GR was completely arrested in HG and HGS vs. G and GS rats; however, for most enzymes HG and overall HGS diets 
significantly blocked antioxidant enzyme expressions. Vázquez-Velasco et al. [17] also showed the negative effects of glucomannan or glucomannan plus spirulinaenriched surimies in $\mathrm{fa} / \mathrm{fa}$ rats. Again, the negative effects of consuming glucomannan plus spirulina together with dietary cholesterol can be suggested.

However, our results clearly differ from those of Vázquez-Velasco et al. [17,18] which found much lower final body weight and cholesterolemia than in this study, both in non-cholesterol and cholesterol fed animals. In addition, liver size was not arrested by GHG and HGS diets as it was in the Vázquez-Velasco et al. studies $[17,18]$ in both cholesterol or non-cholesterol groups. This suggests the importance of the matrix used for incorporating those ingredients.

Some important limitations of this paper are that only male growth fa/fa rats were used. Also, the study was performed with only one concentration of glucomannan or glucomannan plus spirulina added to RP. Future studies should assess potential benefits of different concentrations of glucomannan and glucomannan plus spirulina-RP and in a wider age range of $\mathrm{fa} / \mathrm{fa}$ rats and their possible extrapolation to obese and dyslipidemic humans.

\section{Conclusion}

RP with glucomannan or glucomannan/spirulina affect liver fatty acid profile and antioxidant status. Spirulina added to glucomannan tended to increase diet acceptability and D5D activity. Cholesterol feeding reduced delta-6-desaturase-elongase and D5D activities and increased SCD activity while markedly decreasing most antioxidant enzyme expression and levels and expression of $L d l r$ suggesting that the two mechanisms are linked. Although GHS arrested the hypercholesterolemic effect of dietary cholesterol observed and improved insulin resistance, given by the TyG index in HC animals, this diet negatively affected the delta-6desaturase-elongase activity and markedly depressed the gene expression of antioxidant enzymes and $L d l r$ suggesting that caution needs to be taken when incorporating large amounts of glucomannan or glucomannan plus spirulina to cholesterol enriched diets.

\section{Acknowledgments}

We gratefully acknowledge the foreign fellowship for graduate studies granted by the Consejo Nacional de Ciencia y Tecnología (CONACYT) from Mexico to Laura GonzálezTorres. All authors have significantly contributed to the paper and agree with the present version of the manuscript. FJS-M and JB are the guarantors of the paper and have contributed to the study design, data discussion, and writing of the manuscript. LG-T, C-M, MV-V and JAS-L have contributed to the data acquisition, analysis and writing of the manuscript. IS and CG-F have contributed to the data acquisition and analysis. SB and JB have contributed to data discussion and have made a critical review of the paper.

\section{Disclosure statement}

No potential conflict of interest was reported by the authors.

\section{Funding}

This work was supported by the Spanish projects; [AGL-2008 04892-C03-02]; Consolider-Ingenio 2010 project; [\# CSD2007-00016]; Consejo Nacional de Ciencia y Tecnología (CONACYT).

\section{ORCID}

Jorge A. Santos-López (D) http://orcid.org/0000-0003-49240809

Sara Bastida (D) http://orcid.org/0000-0002-2188-5966

Juana Benedí (D) http://orcid.org/0000-0002-3796-639X

Francisco J. Sánchez-Muniz (1) http://orcid.org/0000-00022660-5126

\section{References}

[1] Aleixandre de Artinano A, Miguel Castro $M$. Experimental rat models to study the metabolic syndrome. $\mathrm{Br}$ J Nutr. 2009;102(9):1246-1253. DOI:10.1017/S0007114509990729

[2] Olivero-David R, Schultz A, Vázquez-Velasco M, et al. Effects of Nori-and Wakame-enriched meats with or without supplementary cholesterol on arylesterase activity, lipaemia and lipoproteinaemia in growing Wistar rats. Br J Nutr. 2011;106(10):1476-1486. DOI:10.1017/ S000711451100198X

[3] Sikder K, Kesh SB, Das N, et al. The high antioxidative power of quercetin (aglycone flavonoid) and its glycone (rutin) avert high cholesterol diet induced hepatotoxicity and inflammation in Swiss albino mice. Food Funct. 2014;5(6):1294-1303. DOI:10.1039/c3fo60526d

[4] Wu W-T, Chen H-L. Konjac glucomannan and inulin systematically modulate antioxidant defense in rats fed a high-fat fiber-free diet. J Agr Food Chem. 2011;59 (17):9194-9200. DOI:10.1021/jf202060p

[5] Sikder K, Das N, Kesh SB, et al. Quercetin and betasitosterol prevent high fat diet induced dyslipidemia and hepatotoxicity in Swiss albino mice. Indian J Exp Biol. 2014;52(1):60-66.

[6] Jiménez-Colmenero F, Sánchez-Muniz FJ, OlmedillaAlonso B. Design and development of meat-based functional foods with walnut: technological, nutritional and health impact. Food Chem. 2010;123(4):959-967. DOI:10.1016/j.foodchem.2010.05.104

[7] Davidson MH, Hunninghake D, Maki KC, et al. Comparison of the effects of lean red meat vs lean white meat on serum lipid levels among free-living 
persons with hypercholesterolemia: a long-term, randomized clinical trial. Arch Intern Med. 1999;159 (12):1331-1338. DOI:10.1001/archinte.159.12.1331

[8] Schultz A, Olivero-David R, Vázquez-Velasco M, et al. Protective effects of sea spaghetti-enriched restructured pork against dietary cholesterol: effects on arylesterase and lipoprotein profile and composition of growing rats. J Med Food. 2014;17(8):921-928. DOI:10.1089/jmf.2013.0100

[9] Garcimartín A, Santos-López JA, Bastida S, et al. Silicon-enriched restructured pork affects the lipoprotein profile, VLDL oxidation, and LDL-receptor gene expression in aged rats fed an atherogenic diet. J Nutr. 2015;145(9):2039-2045. DOI: 10.3945/jn.115.213934

[10] Cheong SH, Kim MY, Sok D-E, et al. Spirulina prevents atherosclerosis by reducing hypercholesterolemia in rabbits fed a high-cholesterol diet. J Nutr Sci Vitaminol. 2010;56(1):34-40. DOI:10.3177/jnsv.56.34

[11] Ratcliffe I, Williams PA, Viebke C, et al. Physicochemical characterization of konjac glucomannan. Biomacromolecules. 2005;6(4):1977-1986. DOI:10.1021/bm0492226

[12] Vuksan V, Jenkins D, Spadafora P, et al. Konjac-mannan (glucomannan) improves glycemia and other associated risk factors for coronary heart disease in type 2 diabetes. A randomized controlled metabolic trial. Diabetes Care. 1999;22(6):913-919.

[13] Sood N, Baker WL, Coleman CI. Effect of glucomannan on plasma lipid and glucose concentrations, body weight, and blood pressure: systematic review and meta-analysis. The Am J Clin Nutr. 2008;88(4):1167-1175.

[14] Al-Ghazzewi FH, Khanna S, Tester RF, et al. The potential use of hydrolysed konjac glucomannan as a prebiotic. J Sci Food Agric. 2007;87(9):1758-1766. DOI:10.1002/ (ISSN)1097-0010

[15] Onishi N, Kawamoto S, Suzuki H, et al. Dietary pulverized konjac glucomannan suppresses scratching behavior and skin inflammatory immune responses in $\mathrm{NC/}$ Nga mice. Int Arch Allergy Immunol. 2007;144(2):95104. DOI:10.1159/000103220

[16] Shimizu H, Yamauchi M, Kuramoto T, et al. Effects of dietary konjac mannan on serum and liver cholesterol levels and biliary bile acid composition in hamsters. J Pharmacobiodyn. 1991;14(7):371-375. DOI:10.1248/ bpb1978.14.371

[17] Vázquez-Velasco M, González-Torres L, López-Gasco $\mathrm{P}$, et al. Effects of glucomannan/spirulina-surimi on liver oxidation and inflammation in Zucker rats fed atherogenic diets. J Physiol Biochem. 2015;71(4):611622. DOI: $10.1007 / \mathrm{s} 13105-015-0425-9$

[18] Vázquez-Velasco M, González-Torres L, LópezGasco P, et al. Liver oxidation and inflammation in $\mathrm{Fa} / \mathrm{Fa}$ rats fed glucomannan/spirulina-surimi. Food Chem. 2014;159:215-221. DOI:10.1016/j.foodchem. 2014.03.015

[19] González-Torres L, Churruca I, Schultz A, et al. Effects of restructured pork containing Himanthalia elongata on adipose tissue lipogenic and lipolytic enzyme expression of normo-and hypercholesterolemic rats. J Nutrigen Nutrigenom. 2012;5(3):158-167. DOI:10.1159/000343722

[20] Sánchez-Muniz FJ, García-Linares MC, García-Arias MT, et al. Fat and protein from olive oil-fried sardines interact to normalize serum lipoproteins and reduce liver lipids in hypercholesterolemic rats. J Nutr. 2003;133(7):2302-2308.

[21] Calder PC. Mechanisms of action of (n-3) fatty acids. J Nutr. 2012;142(3):592S-9S. DOI:10.3945/jn.111.155259

[22] Lu Y, Vaarhorst A, Merry A, et al. Markers of endogenous desaturase activity and risk of coronary heart disease in the CAREMA cohort study. PloS One. 2012;7(7): e41681. DOI:10.1371/journal.pone.0041681

[23] Rudkowska I, Julien P, Couture P, et al. Cardiometabolic risk factors are influenced by Stearoyl-CoA Desaturase (SCD)- 1 gene polymorphisms and n-3 polyunsaturated fatty acid supplementation. Mol Nutr Food Res. 2014;58(5):1079-1086. DOI:10.1002/mnfr.201300426

[24] Jacobs S, Schiller K, Jansen EH, et al. Evaluation of various biomarkers as potential mediators of the association between $\Delta 5$ desaturase, $\Delta 6$ desaturase, and stearoylCoA desaturase activity and incident type 2 diabetes in the European Prospective Investigation into Cancer and Nutrition-Potsdam Study. Am J Clin Nutr. 2015;102 (1):155-164. DOI:10.3945/ajcn.114.102707ajcn102707.

[25] Hozumi T, Yoshida M, Ishida Y, Mimoto H, Sawa J, Doi $\mathrm{K}$, Kazumi T. Long-term effects of dietary fiber supplementation on serum glucose and lipoprotein levels in diabetic rats fed a high cholesterol diet. Endocrine J. 1995;42(2):187-192.

[26] Bermejo-Bescós P, Piñero-Estrada E, Del Fresno AMV. Neuroprotection by Spirulina platensis protean extract and phycocyanin against iron-induced toxicity in $\mathrm{SH}$ SY5Y neuroblastoma cells. Toxicol In Vitro. 2008;22 (6):1496-1502. DOI: 10.1016/j.tiv.2008.05.004

[27] Ou Y, Lin L, Yang X, Pan Q, Cheng X. Antidiabetic potential of phycocyanin: effects on KKAy mice. Pharm Biol. 2013;51(5):539-544. DOI:10.3109/13880209.2012.747545

[28] Reeves PG, Nielsen FH, Fahey Jr GC. AIN-93 purified diets for laboratory rodents: final report of the American Institute of Nutrition ad hoc writing committee on the reformulation of the AIN-76A rodent diet. J Nutr. 1993;123(11):1939-1951.

[29] Schultz A, García-Fernandez RA, Bocanegra A, et al. Effects of seaweed-restructured pork diets enriched or not with cholesterol on rat cholesterolaemia and liver damage. Food Chem Toxicol. 2013;56:223-230. DOI:10.1016/j.fct.2013.02.028

[30] Folch J, Lees M, Sloane-Stanley G. A simple method for the isolation and purification of total lipids from animal tissues. J Biol Chem. 1957;226(1):497-509.

[31] Carrapiso AI, Timón ML, Petrón MJ, et al. In situ transesterification of fatty acids from Iberian pig subcutaneous adipose tissue. Meat Sci. 2000;56(2):159-164. DOI:10.1016/S0309-1740(00)00035-8

[32] Viejo J, Bastida S, Sánchez-Muniz FJ, et al. Effect of olive oil-fried sardine consumption on liver lipid composition and fatty acid cholesterol esterification in hypercholesterolemic rats. Food Sci Technol Int. 2003;9(5):329-338. DOI:10.1177/1082013203038860

[33] Mitra S. Sample preparation techniques in analytical chemistry. John Wiley \& Sons; Hoboken, New Jersey, USA. 2004.

[34] Fleige S, Pfaffl MW. RNA integrity and the effect on the real-time qRT-PCR performance. Mol Aspects Med. 2006;27(2):126-139. DOI:10.1016/j.mam.2005.12.003 
[35] Livak KJ, Schmittgen TD. Analysis of relative gene expression data using real-time quantitative PCR and the 2- $\triangle \Delta$ CT method. Methods. 2001;25(4):402-408. DOI:10.1006/meth.2001.1262

[36] Hissin PJ, Hilf R. A fluorometric method for determination of oxidized and reduced glutathione in tissues. Anal Biochem. 1976;74(1):214-226. DOI:10.1016/0003-2697 (76)90326-2

[37] Guerrero-Romero F, Simental-Mendía LE, GonzálezOrtiz M, et al. The product of triglycerides and glucose, a simple measure of insulin sensitivity. comparison with the euglycemic-hyperinsulinemic clamp. J Clin Endocrinol Met. 2010;95(7):3347-3351. DOI:10.1210/jc.2010-0288

[38] Aprikian O, Busserolles J, Manach C, et al. Lyophilized apple counteracts the development of hypercholesterolemia, oxidative stress, and renal dysfunction in obese Zucker rats. J Nutr. 2002;132(7):1969-1976.

[39] González Canga A, Fernández Martínez N, Sahagún A, et al. Glucomanano: propiedades y aplicaciones terapéuticas. Nutr Hosp. 2004;19(1):45-50.

[40] Friedman JM. Leptin and the regulation of body weigh. Keio J Med. 2011;60(1):1-9. DOI:10.2302/kjm.60.1

[41] Havel PT, Bremer A. Endocrine regulation of energy homeostasis: implications for obesity and diabetes. In: Obesity. Amsterdam: Elsevier; Edited by Serrano Rios M, Ordovás JM, Gutiérrez-Fuentes JA. 2011. p. 107-125

[42] Beynen A, Boogaard A, Van Laack H, et al. Cholesterol metabolism in two strains of rats with high or low response of serum cholesterol to a cholesterol-rich diet. J Nutr. 1984;114(9):1640-1651.

[43] Unger G, Benozzi SF, Perruzza F, et al. Triglycerides and glucose index: a useful indicator of insulin resistance. Endocrinología y Nutrición (English Edition). 2014;61 (10):533-540. DOI:10.1016/j.endoen.2014.11.006

[44] ADA. Diagnosis and classification of diabetes mellitus. Diabetes Care. 2014;37(Supplement 1):S81-S90. DOI:10.2337/dc14-S081

[45] González-Torres L, Vázquez-Velasco M, Olivero-David R, et al. Glucomannan and glucomannan plus spirulina added to pork significantly block dietary cholesterol effects on lipoproteinemia, arylesterase activity, and CYP7A1 expression in Zucker fa/fa rats. J Physiol Biochem. 2015;71(4):773-784. DOI:10.1007/s13105-015-0441-9

[46] Harris WS. n-3 fatty acids and serum lipoproteins: human studies. Am J Clin Nutr. 1997;65(5):1645S-54S.

[47] Doi K, Matsuura M, Kawara A, et al. Influence of dietary fiber (konjac mannan) on absorption of vitamin B12 and vitamin E. Tohoku J Exp Med. 1983;141:677-681. DOI:10.1620/tjem.141.Suppl_677

[48] Sánchez-Muniz FJ, Bastida S. Do not use the Friedewald formula to calculate LDL-cholesterol in hypercholesterolaemic rats. Eur J Lipid Sci Tecnol. 2008;110(4):295301. DOI:10.1002/ejlt.200700280

[49] Bochenek WJ, Rodgers JB. Dietary regulation of 3hydroxy-3-methylglutaryl-CoA reductase from rat intestine. BBA-Lipids Lipid Met. 1979;575(1):57-62. DOI:10.1016/0005-2760(79)90130-9
[50] Huang Y, Nassar B, Horrobin D. Changes of plasma lipids and long-chain $n-3$ and $n-6$ fatty acids in plasma, liver, heart and kidney phospholipids of rats fed variable levels of fish oil with or without cholesterol supplementation. BBA-Lipids Lipid Met. 1986;879 (1):22-27. DOI:10.1016/0005-2760(86)90261-4

[51] Kotronen A, Seppänen-Laakso T, Westerbacka J, et al. Hepatic stearoyl-CoA desaturase (SCD)-1 activity and diacylglycerol but not ceramide concentrations are increased in the nonalcoholic human fatty liver. Diabetes. 2009;58(1):203-208. DOI:10.2337/db08-1074

[52] Reiner Ž, Catapano AL, De Backer G, et al. ESC/EAS Guidelines for the management of dyslipidaemias. Eur Heart J. 2011;32(14):1769-1818. DOI:10.1093/eurheartj/ ehr158

[53] Zhang Z, Yang Z, Zhu B, et al. Increasing glucose 6phosphate dehydrogenase activity restores redox balance in vascular endothelial cells exposed to high glucose. PloS One. 2012;7(11):e49128. DOI:10.1371/ journal.pone.0049128

[54] Bocanegra A, Beneduí J, Sé Nchez-Muniz FJ. Differential effects of konbu and nori seaweed dietary supplementation on liver glutathione status in normoand hypercholesterolaemic growing rats. $\mathrm{Br} \mathrm{J}$ Nutr. 2006;95(04):696-702. DOI:10.1079/BJN20051682

[55] Schultz A, González-Torres L, Olivero-David R, et al. Wakame and Nori in restructured meats included in cholesterol-enriched diets affect the antioxidant enzyme gene expressions and activities in Wistar rats. Plant Foods Hum Nutr. 2010;65(3):290-298. DOI:10.1007/ s11130-010-0179-Z

[56] Xu Y, Osborne BW, Stanton RC. Diabetes causes inhibition of glucose-6-phosphate dehydrogenase via activation of PKA, which contributes to oxidative stress in rat kidney cortex. Am J Physiol-Renal Physiol. 2005;289(5): F1040-F7. DOI:10.1152/ajprenal.00076.2005

[57] Christon R, Haloui RB, Durand G. Dietary polyunsaturated fatty-acids and aging modulate glutathione-related antioxidants in rat-liver. J Nutr. 1995;125(12):30623070.

[58] Santos-López JA, Garcimartin A, Merino P, et al. Effects of silicon vs. hydroxytyrosol-enriched restructured pork on liver oxidation status of aged rats fed high-saturated/ high-cholesterol diets. PloS One. 2016;11(1):e0147469. DOI:10.1371/journal.pone.0147469

[59] Schultz A, Benedí J, González-Torres L, et al. Effects of diet enriched with restructured meats, containing Himanthalia elongata, on hypercholesterolaemic induction, CYP7A1 expression and antioxidant enzyme activity and expression in growing rats. Food Chem. 2011;129(4):1623-1630. DOI:10.1016/j.foodchem.2011. 06.019

[60] Cordero Herrera I. Mecanismos de acción de los flavanoles del cacao en las células hepáticas durante la resistencia a la insulina y la diabetes: estudio en cultivos celulares y en animales de experimentación [European Thesis]. Madrid: Universidad Complutense de Madrid; 2015. 